DOI 10.14746/ssp.2018.3.8

\author{
Anna AnTCZAK \\ University of Finance and Management in Warsaw \\ (Wyższa Szkoła Finansów i Zarządzania w Warszawie) \\ Zdzisław ŚLiwA \\ University of Lower Silesia (Dolnośląska Szkoła Wyższa), \\ Baltic Defence College, Tartu, Estonia
}

\title{
Security dilemmas of the Baltic region
}

\begin{abstract}
The aim of the paper is to provide an analysis of security in the Baltic region, regarding the decision taken by NATO toward strengthening the security of the Baltic region when facing the threat from the East. It looks deeper into geostrategy as one of the keys to understand the vagaries of security dilemmas in the Baltic area. The article presents a situation analysis from both the Baltic states' and NATO's perspectives, having as a background recent actions undertaken by Russia.
\end{abstract}

Key words: Baltic region, security, Russian Federation, NATO, deterrence

$\mathbf{T}$

The geostrategic location of Estonia, Latvia and Lithuania was always affected by stronger neighbors influencing their drive toward independence. The fate of being a part of Russian 'buffer zone' was one of the factors shaping their political situation, which is still playing a role in Kremlin's drive to rebuild its past empire. The importance of the so-called near neighborhood was expressed in the Russian Military Doctrine published in December 2014 by defining threats like NATO build-up and expansion, creation of NATO infrastructure next to Russian borders, destabilization of states or regions, deployment of military units to countries bordering Russia, or development of strategic missile defense systems (Военная доктрина Российской Федераиии, 2014). Therefore, "the Russian government defines security along its borders as a top priority" (Zakem, Saunders, Antoun, 2015, p. 14) which is linked to allocation of resources and is among reasons the West Military District is the most powerful one among all the four districts. The pressure from Russia is a constant dilemma faced by the Baltic states; however, these small countries were strong enough to survive as nations, preserving their national identity, leading to their emergence from the chaos of history. 
The article will try to provide answers to the following questions: what is the geostrategic situation in the Baltic region?; what is the attitude of NATO towards the situation in the Baltic states?; and, what is the level of security in the Baltic region? The aim of the paper is to provide an evaluation of the decision taken by NATO toward strengthening the security of the Baltic region when facing the threat from the East. It will be achieved by providing an in-depth analysis of the security environment in the Baltic region with the use of an analysis of the literature, observation, comparison to past events and an analysis of the behavior of various actors. The article will not be set within any specific theoretical framework, as its aim is not to test the analytical usability of any theory, but to provide a practical analysis and evaluation of security conditions in the Baltic states. The initial assumption is that the decision and actions taken by NATO support stronger deterrence against Russia by showing unity of effort and cohesion. However, it is obvious that the actions taken and military deployments to the three Baltic states and Poland are not powerful enough to fully prevent any attempt to occupy the region or its parts, taking into consideration the capabilities and speed of possible operations (e.g. the Zapad series of exercises conducted in the past few years). The situation is not improving, regarding the continuous modernization of Russian armed forces, which must be faced by stronger presence based on a cohesive Alliance approach to security in a broader sense. The paper starts with an overall description of the current security situation in the region. It continues with actions taken by NATO in order to protect its eastern members and later draws a concise picture of the geostrategic situation of the Baltic states. It closes with final remarks on possible developments.

\section{Geostrategic insight}

The instability of the eastern neighborhood and unpredictable direction of Russian foreign policy, as well as the option to use the military instrument of power on its borders, both theoretically and in practice, is a major concern for the Baltic region and beyond. This is linked with the relatively realistic assessment of the security situation by the governments of Estonia, Latvia and Lithuania. It is generally assumed that a more democratic Russia - if we can use this term - could support overall regional stability and beyond. However, if Moscow continues 
with its non-democratic actions, the security environment will be more sensitive with a possibility of collapsing into the nightmare of a new Cold War or even actual war. It might even be worth asking if we already have a new Cold War. The Russian decision in 2015 to withdraw from the Treaty on Conventional Armed Forces in Europe and to continue their military build-up on NATO's eastern flank causes real and validated concerns. These are expressed by leaders in the region, but also by well-known think-tanks, such as RAND (Shlapak, 2017), the Potomac Foundation, Chatham House, and also regional ones such as the Center for Security and Strategic Research (Praks, 2015) and such researchers as Juri Luik, General (ret.) Wesley Clark or General (ret.) Sir Richard Shirreff (Clark, 2016). The reinforcement of the Kaliningrad Oblast (creating a highly militarized enclave) raises 'isolation' concerns, and that factor demonstrates the limited will of Russia to move toward cooperation, and rather the drive toward confrontation and exerting pressure on democracies located in its vicinity. The constant build-up of Anti Access/Area Denial (AA/AD) capabilities shows Russia is enhancing its defensive strength, but it could also be used for offensive purposes, by covering attacking units engaged in achieving limited objectives. It is essential to keep a close eye on the enlargement of AA/AD potential, as "Russia would be capable not just of sealing off the Baltic states in the 'bubble' that covers air, sea and land dimensions, but also of fiercely contesting other spaces of critical importance to military operations - in the electromagnetic spectrum, cyberspace, and even outer space by using anti-satellite capabilities" (Clark, 206, pp. 12-13).

The military exercise scenarios are varying year by year, and although they are officially limited in scale and are announced as being counter-terrorist in nature, the scale, quantity of troops and types of equipment do not support such a message. They are clearly aimed at presenting Russia's ability and readiness to plan and execute large scale joint operations (within the Collective Security Treaty Organization, but rather not with major partners in the Shanghai Cooperation Organization). The planned utilization of nuclear weapons, the use of nuclear submarines, heavy armor formations, strategic aviation and other 'hard' tools are definitely not aimed at combating terrorists. The creation of Tank and Combined Arms Armies and merging brigades into divisions shows a growing ability and readiness to conduct operations along separate avenues of approach and mobility corridors. The Zapad (Russian 
for west) 2017 exercises were a demonstration not only of military capabilities and numbers, as these were just episodes within a sequence of other small exercises both before and after them, but also displayed Russia's potential to be part of a bigger scenario played out to a complex operational plan. The purposefully shaped propaganda reinforced messages in Russian society, strengthening its metanarratives. Moreover, officially available data is an important part of maskirovka (Russian for military deception) to show power and hide real deficiencies and problems. The modernization of Russia's armed forces is going slowly, the Sukhoi Su-57 is still not in units, the T-14 Armata is not to enter service in the expected numbers; the 2S35 Koalitsiya-SV has been postponed to 2020; no purchases of major surface navy ships are planned, and there are further symptoms of deficiencies. Nevertheless, Russia should never be underestimated, as it is a strong regional actor with global ambitions. From the military point of view, it possesses a very clear and direct chain of command allowing it to start operations at short notice, denying time for NATO to react in sufficient force. It is underpinned by a National Defense Control Center as "a new mechanism in the operation of state defense" (Vershinin, 2016, Russia Opens, 2014). It makes it possible to monitor the situation in the country and share information among all security related national entities, which is key to ensure the recognition of early warning indicators and a comprehensive approach to national defense using all instruments of power in an orchestrated way. Russia is also exercising its 'hybrid warfare' instruments to destabilize its neighbors on the one hand and to enhance its own propaganda potential on the other.

The nations of Estonia, Latvia and Lithuania are under constant INFOOPS attack aiming to divide and destabilize them internally and to isolate externally. All tools are utilized, and this creates an effect of constant uncertainty, influencing them all. The evolving scenarios extend the uncertainty about Russia's intentions and create a dilemma about what regional armed forces should be procured to meet the threat. Thus, a question arises of whether these countries should be ready to face conventional or 'hybrid threats'? They are different in nature, demanding distinct sets of capabilities and tools to oppose them. Is it clear that open aggression would activate Article 5, therefore all actions which could not activate Article 5 would cause a dilemma in NATO regarding possible reactions, and so Russia can be expected to behave in this way. The efficiency of cooperative security is based on 
involvement and synergy of Estonia, Latvia and Lithuania, but similarly on the direct and constant involvement of all NATO allies and external actors in building regional stability and peace. Likewise, the security of each single nation is based on other countries' willingness to pay the price, bearing in mind that "an increase in one state's security decreases the security of others" (For more about the concept see: Jervis, 1978, pp. 167-214; and also: Coper, 2012, p. 177). NATO and the EU, and their ability to use cohesively all instruments of power in concert to minimize threats is intended to produce positive stability and to counterbalance any other actor, especially Russia. The Wales Summit in 2014 supported the assurance concept, and the Warsaw Summit in 2016 implemented stronger deterrence actions, with the Enhanced Forward Presence (EFP) battalion-size battlegroups as a symbolic component of NATO cohesion and involvement in strengthening Estonia, Latvia, Lithuania and Poland's sovereignty. The EU is reinforcing sanctions, trying to create the political isolation of Russia, due to its understanding of the possible long-term consequences of any conflict escalation in the region. Both NATO and the EU understand that any successful attempt by Russia to damage the cohesion of these organizations could affect their internal solidarity, leading to disintegration and chaos in the whole continent and beyond.

\section{NATO attitude}

The Wales Summit in 2014 was conducted just a few months after the Crimea crisis, which showed the Kremlin's assertive policy, and its ability to exploit any opportunities at short notice. Part of a sovereign state was annexed by Russia, but the global reactions were inadequate. Furthermore, the enlargement of the NATO Response Force (NRF) and creation of the Very High Readiness Joint Task Force - VJTF (Wales Summit Declaration, 2016) was decided, to show the enhanced readiness of Western troops, albeit they were still to be assembled. The Baltic states' perception of the growing Russian threat was not answered properly, and was even underestimated. Events proved that assurance was not sufficient, and company size units were not powerful enough as a deterrent, especially as the crisis in the South (migrant issues) caused some nations to be more concerned about that than the war in Ukraine. The Baltic states have historical experience of Russia, and so they never 
overlooked the military threat from the eastern neighborhood. This is also linked to the fact that they have credible and reliable expertise regarding Russian military capabilities, tactics and techniques. This fact is of great significance, and there is an ongoing need for such knowledge. The Warsaw Summit in 2016 pushed the Alliance more toward deterrence, although still on a limited scale. To date, NATO member states are not able to invest more militarily, and there are real limitations of the three Baltic states to host bigger forces. It is also a matter of will, based on each single nation's assessment of the direct threat against their national security.

However, it is clear that the Alliance will not be inactive in the case of any aggression, which will cause the direct involvement of NATO soldiers in the fight. Aggression will evoke a comprehensive reaction from NATO, and it will also cause the extension of sanctions against Russia in cooperation with the EU. The combination of political isolation, NATO's military capabilities and economic pressure will have a devastating effect on the Russian government and society. This would probably be too much for the current authorities to handle in the long term. The need to take a decisive stand has been promoted especially by the Baltic states, Poland and Romania, which have used every occasion during NATO and EU meetings to advocate the issue. The Warsaw Summit decision to establish the Enhanced Forward Presence (EFP) in Estonia, Latvia, Lithuania and Poland (see Fig. 1) with respectively the United Kingdom, Canada, Germany and the United States as framework nations, was a step forward toward facing the threat (Warsaw Summit Communiqué, 2017). Moreover, it sent a message to the societies of eastern Europe, confirming the cohesion and determination of the Alliance, to enhance belief and trust among member nations and to reassure these countries that they will not be left alone.

The Enhanced Forward Presence has already been deployed in the above-mentioned states, proving the decisiveness of the Alliance. However, they are still facing command and control issues, logistics difficulties, differing tactical procedures and even language challenges, but their presence is linked with a strong political message. The issue is the will to preserve the continuity of those rotationally deployed troops when the perception of threat starts to diminish. The decision to create the Headquarters Multinational Division Southeast was another important factor related to enhancing command and control in the region, as that aspect is still a challenge. 


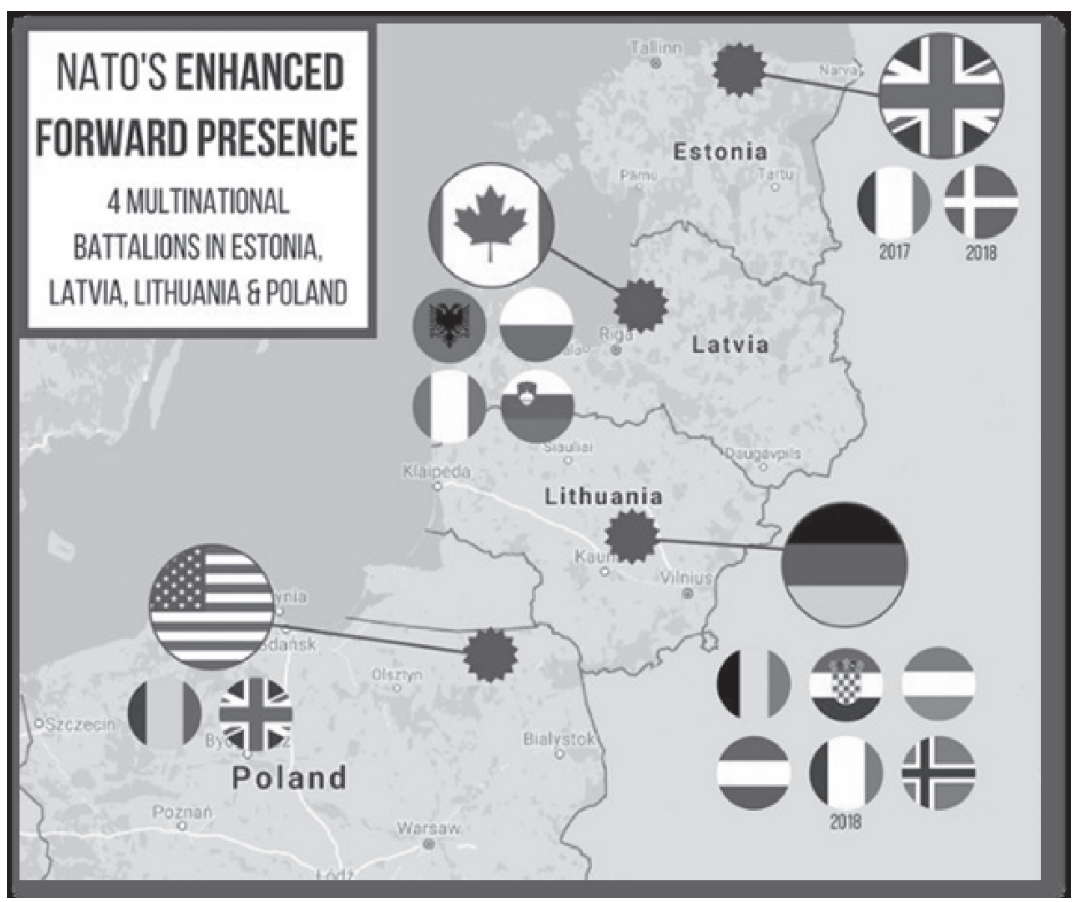

Fig. 1. Location of NATO's Enhanced Forward Presence units

Source: NATO's Enhanced Forward Presence, US Embassy in Tallinn, Twitter post October 31, 2016.

The NATO Force Integration Units (NFIUs) concept, initiated during the Wales Summit and composed primarily of six NFIUs, was further strengthened during the Warsaw Summit by creation of two more NFIUs. Their role was to facilitate the deployment of major NATO units and to "support collective defence planning, provide expertise and prepare the ground for the deployment of the Very High Readiness Joint Task Force" (New Units for the New Challenges, 2017). Thus, they were designed in general to prevent conflict, rather than to escalate or provoke it, similarly to the EFP. The decisions toward stronger deterrence are to be continued, which is recognized by Russia and challenged by confrontational actions. The rotational presence does not violate the agreement between NATO and Russia signed in 1997 during the NATO Summit, stating that "the Alliance will carry out its collective defence and other missions by ensuring the necessary interoperability, integration, and capability for reinforce- 
ment rather than by additional permanent stationing of substantial combat forces" (Founding Act on Mutual Relations, 1997). It is also necessary to bear in mind that this agreement was signed under a different security environment, which was quite specific.

In spite of the decisions mentioned, provocative Russian activities in the vicinity of the Baltic states have been continued and even escalated after the Warsaw Summit. Selected units from three military districts (Central, Western, Southern MDs), North Fleet, Aerospace Forces and Airborne Troops were put into full combat readiness at the end of August 2016. It was also a precondition for the strategic level command-staff exercise of the Southern Military Districts codenamed Caucasus 2016 in which approximately 12,500 troops were supported by aviation and heavy equipment. The number of soldiers participating in an exercise is always below 13,000, following the 2011 Vienna Document on Confidence- and Security-Building Measures, but other troops are exercising in different locations and time frames. The scale and the snap activation of Zapad and other similar exercises are a clear message directed at NATO, showing that the decisions of the Warsaw Summit do not change anything, and that the scale of ongoing NATO deployment is minor compared to the real capabilities of the Russian Federation. It also puts pressure on NATO, as it again draws a picture of Russia as an unpredictable country, ready to further challenge the already shaken regional stability. Its military activities, supported by ongoing modernization of its armed forces require a consolidated and solid response, as every sign of indecisiveness or lack of cohesion within the Alliance could be a trigger to execute more than just 'snap exercises.' This is connected with NATO's constant presence in the region and possession of credible capabilities allowing it to face a possible threat, including the socalled 60-hours RAND corporation scenario, which conducted war-games, and estimated that Russian troops could reach Tallinn and Riga in just 60 hours (Shlapak, 2016, p. 4). The assessment was based on four factors: overall correlation of the ratio of forces; significant Russian advantage in tactical and operational firepower; limited maneuverability of NATO forces and limited time for NATO airpower to sufficiently combat Russian units before they reach their objectives (Shlapak, 2016, pp. 4-6). The military scenario is not likely now, but following the New Generation Warfare concept presented by General Gerasimov, ${ }^{1}$ the threat still exists and refers to

${ }^{1}$ For more about the concepts of the General Valery Gerasimov see: Герасимов, 2013, and also Thomas, 2016, pp. 16-19. 
other than military instruments of power. ${ }^{2}$ The exercise Zapad 2017 in September was an element of applying pressure to the whole of Eastern Europe by displaying military capabilities and the readiness to initiate operations at short notice. Although the focus of attention was on the Belarus part of the drills, the major deployments were conducted in the Western Military District and in the Arctic (Stormark, 2017). The exercise was also to present that Belarus is and will remain a part of the Russian area of influence, and its territory is potentially to be used for military operations, which significantly complicates the defensibility of NATO, and specifically Poland, putting it in a very unfavorable geostrategic position.

\section{Situation in the Baltic states}

The Baltic states met their allied commitments by participating in all major NATO operations abroad within their limited capabilities, and this was also one of the reasons for shifting national resources toward creating the expeditionary capabilities required to fight arm-in-arm with their NATO partners, demonstrating their credibility and reliability. As for now, Estonia, Latvia and Lithuania are recognized as fragile partners, requiring stronger deterrence capabilities and support with respect to collective defense within Article 5 of the Washington Treaty. They deserve such support, as their failure would also mean the failure of the whole of NATO as a security organization which would further destabilize security, not only in Europe, but also beyond the region.

The Baltic states are now investing in their military capabilities, developing armed forces, combat power, reinforcing their territorial defense posture, organizing information campaigns to highlight the risks, increasing military budgets, but despite this, they are in no position to face the threat alone. They are investing in modernization projects, developing military infrastructure to improve their Host Nation Support capabilities, but they also need to be sponsored strongly by NATO as an organization, as it is its common interest both now and in the long-term perspective. Examples of developing capabilities are mechanization of combat brigades (in spite of the variety of combat platforms used by each nation), investment in anti-armor and air defense (short range in all

${ }^{2}$ NATO recognizes four national instruments of power: military, political, economic, and civil - MPEC (See: Allied Command, 2013, pp. 1-9). 
countries and mid-range air defense in Lithuania), and an extensive program of exercises to improve interoperability. Moreover, strong investment in territorial defense forces such as the Estonian Defence League (Est. Kaitseliit), Latvian National Guard (Lat. Zemessardze) or Lithuanian National Defence Volunteer Forces shows their readiness to face conventional and unconventional threats and the growing consolidation of the societies. In 2015, during a tripartite meeting of Latvian, Lithuanian and Estonian Defense Ministers, the three countries recognized "the need to develop joint solutions for air defense and unified infrastructure to support a long-term allied presence in the Baltic countries" (Latvia and Lithuania to sign joint defense purchase plan, 2016). The following year, the Ministers of Defense of Latvia and Lithuania signed a joint communiqué on September 15, 2016, aiming to synchronize the procurement of military equipment, which is a step toward the further consolidation of their military capabilities and enhancing their common defense capabilities.

Cooperation is, however, still an issue, mainly due to the limited number of projects planned and executed together, so "the Baltic states should reassess the importance of their trilateral cooperation" (Romanovs, Andzans, 2017, p. 22). There were also projects in the past involving other countries like Poland, but they have since almost entirely disappeared. The Baltic states must rethink such possibilities, along with initiating closer cooperation with their neighbors, as they share a common operational space and could share experiences in certain fields. As an option, they could share experiences with Poland, which is now creating its own Territorial Defense Force. A common regional approach and links with Poland are important factors also with respect to the so-called Suwalki Gap (Figure 2), which is perceived as "the most vulnerable spot in the Western alliance" (Barnes, 2016). The importance of Poland for its geostrategic locations is vital in the current security setup in the Baltic region. General Ben Hodges, the former commander of the United States Army Europe, emphasized this very strongly saying that "Poland has become for the United States Army the centre of gravity for everything that we are doing in terms of deterrence" (Poland 'centre of gravity', 2017).

In relation to the Suwalki Gap, he recognized it as one of possible hotspots in the current security setup and that "narrow piece of land connecting two NATO member states Poland and Lithuania - the Suwalki Gap - could potentially be a target of Russian military aggression" (Gri- 


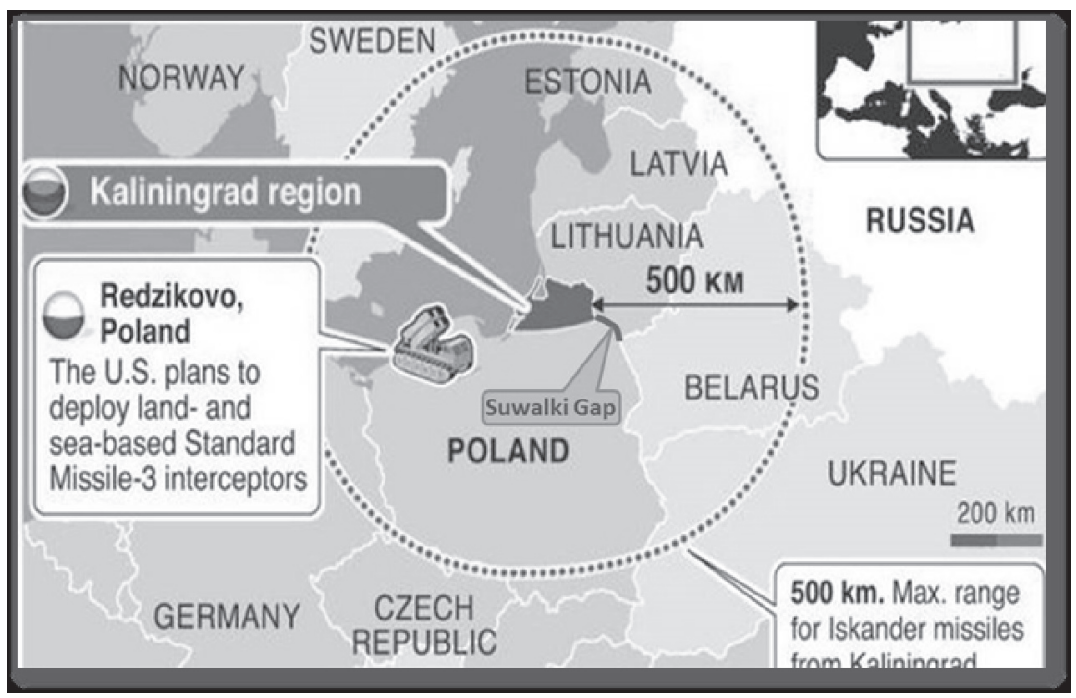

Fig. 2. The location of the Suwalki Gap in relation to Kaliningrad Oblast

Source: E. Walker, UC Berkeley, Eurasian Geopolitics, Word Press, 29 March 2016, https: //eurasiangeopolitics.com/2016/03/29/putins-dilemma-why-pushing-back-against-natoencroachment-makes-russias-nato-problem-worse/suwalki-gap/\#main, October 22, 2017.

gas, 2016). That term also has historical connotations, but whereas during the Cold War "the concept of the 'Fulda Gap' was a symbol of Allied solidarity in German defense, the 'Suwalki Gap' could turn into a symbol of the weakness of the West" (Suwalki Gap, 2016; Elak, Śliwa, 2016). The other two hotspots mentioned were Syria and Donbas. The real conventional threat could come from the east, and the lack of capabilities to face it could even lead to the disintegration of NATO, as the occupation of the Suwalki area could cut the Alliance area into pieces. This is vital for the Baltic states, and they should not be suppressed by Russia only because they are small. Since 2004, they have relied on NATO as a security organization to fight together and to defend them if necessary. Real deterrence, however, requires a long-term vision, and not only among the three Baltic states, but also within the whole of NATO. It necessitates a clear understanding and consensus of 29 nations by recognizing that regional challenges are not really regional in nature, as they are capable of changing the current security environment in the whole of Europe including the possibility of undermining transatlantic relations, which have been fundamental for common security. 


\section{Conclusion}

The initial assumption seems to be confirmed; however, it is obvious that the geostrategic position of the Baltic states is extremely difficult, and makes them vulnerable to potential Russian attacks. Despite the fact that NATO has undertaken some declaratory and real actions to support the Baltic states, this may not be enough in the future, especially when it comes to cyber-attacks (cyberterrorism). It is also essential that all NATO member states cooperate and act coherently, as erosion of NATO's unity may be the greatest threat, not only for the Baltic states, but for all members of the alliance.

The situation in the Baltic region is and will remain complex in the coming years, as Russia will continue its pragmatic approach to meeting own aims, including maintaining the pressure on individual nations and on the Alliance as a whole. Nevertheless, NATO Secretary General, Jens Stoltenberg, said: "NATO's two-track approach toward Russia is the right one. We need more defence and more dialogue. NATO is delivering both" (Opinion piece by NATO Secretary General Jens Stoltenberg, 2016). Thus, the forward military presence should be linked to efficient dialogue with Russia. Such an approach keeps the door open, but political discourse must be accompanied by showing real power. Some nations, including Russia, perceive a lack of power as a weakness worth exploiting. Such initiatives of the Warsaw Summit as The United States' European Reassurance Initiative, the Transatlantic Capability Enhancement and Training Initiative, UK-France Combined Joint Expeditionary Force concept (Warsaw Summit Communiqué, 2016), or the Visegrad Group's decision to provide rotational presence are important. Nevertheless, Russia is believed to be consuming its reserve funds and will have a problem paying its budget deficit, which means that if sanctions are not waived, the country may find itself on the edge. However, the improvement in the raw materials market allows cautious optimism about the Russian economy. Nevertheless, if the economy declines again in the future, it will require decisions by the Kremlin, and one of them could be linked with playing the military card again. It is hard to predict whether this will be in the Caucasus, or Ukraine again, but also the Baltic region could be targeted by the use of hybrid tools. Thus, the decisions to support the region could have come too late to face the threat, especially as the NATO battalions deployed in 2017 are good tools of deterrence, but they are not capable of dealing with direct aggression. Standing forces would 
be a more appropriate solution, but this would require an allocation of additional troops and funds from the sending nations, and a significant investment by the host nations in the Baltic region to deliver the required level of Host Nation Support. There are also limits in terms of operational area, as it cannot allow the deployment of major military forces due to the limited infrastructure and the size of the area. Moreover, they could be cut off from the main NATO area (if the Suwalki Gap is blocked, even temporarily). Without support and sustainment, they could be treated as hostages and a 'card to play.'

There are many questions that need an answer regarding the situation in Eastern Europe. The last change of NATO Command Structure did not introduce a shift of any HQ towards the east to facilitate the consolidation of the capabilities to run operations there. Multinational Corps North East is undergoing reorganization and transformation into a High Readiness Forces HQ and this is a good step, including achieving full operational capabilities by the subordinated NATO Force Integration Units (NFIUs). Along with the Enhanced Forward Presence battlegroups this is a significant and visible footprint showing a real regional focus and the importance and validity of NATO's collective defense decisiveness. However, the greatest concern is whether the response is adequate to the risk of aggression towards the Baltic states. Is it enough to deter, taking into account the whole spectrum of threats? What is the future of the US presence and engagement in Europe? Will NATO be ready to deploy more forces in the region (e.g. brigade size units) to supplement the three Baltic nations' military capabilities once the infrastructure allows such an action? Will all NATO members be ready to continue the current drive towards Russia, taking into consideration their particular national interests? All these questions are still valid and must be answered soon, as they are critical for NATO as a security organization to preserve its credibility and unity, showing readiness to take decisive steps to support each of its member states.

\section{Bibliography}

Allied Command Operations Comprehensive Operations Planning Directive COPD Interim V2.0. (2013), SHAPE, Brussels.

Barnes J. (2016), Closing the Gap: NATO Moves to Protect Weak Link in Defenses Against Russia, "Wall Street Journal," New York, http:/www.wsj.com/ar- 
ticles/closing-the-gap-nato-moves-to-protect-weak-link-in-defenses-againstrussia-1466205268, 12 October 2017.

Clark W., Luik J., Ramms E., Shirreff R. (2016), Closing NATO's Baltic Gap, International Centre for Defence and Security, Tallinn.

Coper B. S. (2012), Refugees and national Security: Crossing the Threshold of Insecurity, in: Refugees Worldwide. Volume 1: Global perspective, eds. D. Elliott, U. A. Segal, ABC-CLIO, Santa Barbara.

Elak L., Sliwa Z. (2016), The Suwalki Gap-NATO’S fragile hot spot, “The Scientific Quarterly," no. 2, vol. 103, The War Studies University, Warsaw.

Founding Act on Mutual Relations, Cooperation and Security between NATO and the Russian Federation signed in Paris, France (1997), NATO Website, https:// www.nato.int/cps/en/natohq/official_texts_25468.htm, last updated 12 October 2009, 28 October 2017.

Grigas A. (2016), NATO's Vulnerable Link in Europe: Poland's Suwalki Gap, The Atlantic Council, http://www.atlanticcouncil.org/blogs/natosource/nato-svulnerable-link-in-europe-poland-s-suwalki-gap, 14 October 2017.

Jervis R. (1978), Cooperation under security dilemma, "World Politics," vol. 30, no. 2.

Latvia and Lithuania to sign joint defense purchase plan (2016), Latvian Public Broadcasting English-language service, http://eng.lsm.lv/article/society/defense/latvia-and-lithuania-to-sign-joint-defense-purchase-plan.a200830/, 23 October 2017.

New Units for the New Challenges (2015), the Website of the Multinational Corps Northeast, https://mncne.pl/new-units-for-the-new-challenges/, 28 October 2017.

Opinion piece by NATO Secretary General Jens Stoltenberg (2016), NATO Website, http://www.nato.int/cps/en/natohq/opinions_134210.htm, 27 October 2017.

Poland 'centre of gravity' for US Army in Europe (2017), "Worldbulletin News," http://www.worldbulletin.net/europe/192946/poland-centre-of-gravity-forus-army-in-europe, 12 October 2017.

Praks H. (2015), Hybrid or Not: Deterring and Defeating Russia's Ways of Warfare in the Baltics - the Case of Estonia, "Research Paper," no. 124, NATO Defence College, Rome.

Romanovs U., Andzans M. (2017), The Trilateral Military Cooperation of the Baltic States in the "New Normal" Security Landscape, in: Security in the Baltic Sea Region: Realities and Prospects The Rìga Conference Papers 2017, eds. A. Sprūds, M. Andžāns, Latvian Institute of International Affairs, Riga.

Russia Opens New National Defense Control Center: Tech Savvy and Prompt (2014), "Sputnik News," Military and Intelligence, https://sputniknews.com/military/201412011015358641/, 27 November 2017.

Shirreff R. (2016), War with Russia, Coronet Books, London.

Shlapak D. A. (2017), Deterring Russian Aggression in the Baltic States. What it Takes to Win, RAND Corporation, Santa Monica 2017. Testimony of D. A. Shlapak 
before the Committee on Armed Services Subcommittee on Tactical Air and Land Forces United States House of Representatives, Washington.

Shlapak D. A., Johnson M. W. (2016), Reinforcing Deterrence on NATO's Eastern Flank. Wargaming the Defence of the Baltics, RAND Corporation, Santa Monica.

Stormark K. (2017), Russian forces exercised attack on Svalbard, "AldriMer," no. 18, https://www.aldrimer.no/russian-forces-exercised-attack-on-svalbard/, 23 October 2017.

Suwalki Gap (2016), Global Security Org., https:/www.globalsecurity.org/military/ world/europe/suwalki-gap.htm, 14 October 2017.

Thomas T. (2016), Thinking Like A Russian Officer: Basic Factors And Contemporary Thinking On The Nature of War, The Foreign Military Studies Office (FMSO), Fort Leavenworth.

Vershinin A. (2016), Russia's military command center: Sending orders from the heart of Moscow, https:/www.rbth.com/defence/2016/01/04/russias-militarycommand-center-sending-orders-from-the-heart-of-moscow_555889, 27 November 2017.

Vienna Document 2011 on Confidence- and Security-Building Measures (2011), Organization for Security and Co-operation in Europe (OSCE), Vienna.

Wales Summit Declaration. Issued by the Heads of State and Government participating in the meeting of the North Atlantic Council in Wales (2016), NATO Website, https://www.nato.int/cps/ic/natohq/official_texts_112964.htm, 23 October 2017.

Warsaw Summit Communiqué (2016), Warsaw, http://www.nato.int/cps/en/natohq/official_texts_133169.htm, 28 October 2017.

Zakem V., Saunders P., Antoun D. (2015), Mobilizing Compatriots: Russia's Strategy, Tactics, and Influence in the Former Soviet Union, CNA's Occasional Paper.

Военная доктрина Российской Федерации (2014), Moscow, Website of the: Совет Безопасности Российской Федерации, The Security Council of the Russian Federation, http://www.scrf.gov.ru/documents/18/129.html, 6 November 2017.

Герасимов В. (2013), Ценность Науки в Предвидении. Новые вызовы требуют переосмыслить формы и способы ведения боевых действий, "Военнопромышленный курьер”, no. 8 (476), Moscow, http://www.vpk-news.ru/ articles/14632, 26 September 2017.

\section{Dylematy bezpieczeństwa regionu baltyckiego}

\section{Streszczenie}

Artykuł ma na celu dostarczenie analizy przestrzeni bezpieczeństwa regionu bałtyckiego w świetle decyzji podjętej przez NATO dotyczącej wzmocnienia bezpieczeń- 
stwa państw bałtyckich ze względu na niebezpieczeństwo grożące im od Wschodu. Dostarcza analizy sytuacji regionu z geostrategicznego punktu widzenia jako jednego z kluczowych elementów umożliwiających zrozumienie meandrów związanych $\mathrm{z}$ bezpieczeństwem regionu bałtyckiego. Artykuł prezentuje analizę sytuacji z obu perspektyw: państw bałtyckich oraz NATO, mając za tło ostatnie zachowania Rosji.

Słowa kluczowe: region bałtycki, bezpieczeństwo, Federacja Rosyjska, NATO, odstraszanie 